Pacific Journal of Mathematic 


\title{
SYMMETRIC TWINS AND COMMON TRANSVERSALS
}

\author{
M. KatchaLSKI AND A. LIU
}

\begin{abstract}
In this paper, we study the properties of certain families of sets on the circle and use the result to obtain a theorem on common transversals for sets in the plane.
\end{abstract}

1. Introduction. The standard Helly type results (see [2]) are essentially of the following nature:

If each subfamily of a given size of a family of sets has a certain property, then the whole family has the same property.

Our results in this paper are in a different form:

Let $\mathscr{F}$ be a family of $n$ sets where $n$ is sufficiently large. For any constant $c, 0<c<1$, there exists an integer $k=k(c), 1<k<n$, such that if each subfamily of $\mathscr{F}$ of size $k$ has a certain property, then some subfamily of $\mathscr{F}$ of size at least $c n$ has the same property.

A symmetric twin (see [3] for other kinds of twins) is a subset of a circle which consists of two closed arcs symmetric about the center of the circle. We shall also consider the whole circle as a degenerate symmetric twin. The property of interest here is that of having nonempty intersection. Our result is:

THEOREM A. Let $\mathscr{F}$ be a family on $n$ symmetric twins on the same circle and let $k$ be an integer, $1<k<n$. If each subfamily of $\mathscr{F}$ of size $k$ has nonempty intersection, then some subfamily of $\mathscr{F}$ of size at least $n(k-2) /(k+1)$ has nonempty intersection.

We point out that given $0<c<1$, we can choose $k$ so that $(k-2) /(k+1)>c$ provided that $n$ is sufficiently large.

For families of connected closed sets in the plane, the property of interest here is that of having a common transversal (see [4]), which is a straight line interesting all members of the family. Our result is:

THEOREM B. Let $\mathscr{F}$ be a family of $n$ connected closed sets in the plane where $n$ is sufficient large. For any constant $c, 0<c<1$, there exists an integer $k=k(c), 1<k<n$, such that if each subfamily of $\mathscr{F}$ of size $k$ has a common transversal, then some subfamily of $\mathscr{F}$ of size at least $n$ has ca common transversal.

To prove Theorem B, we shall make use of Theorem A as well as yet another result of similar nature, proved in different termi- 
nology by Abbott and Katchalski ([1]):

TheOREm C. Let $\mathscr{G}$ be a family of $n$ closed intervals on the line where $n$ is sufficiently large. Let $\alpha$ be any constant, $0<\alpha<1$. If at least $\alpha\left(\begin{array}{l}n \\ 2\end{array}\right)$ of the pairs of intervals have nonempty intersections, then some subfamily of $\mathscr{G}$ of size at least $(1-\sqrt{1-\alpha}) n$ has nonempty intersection.

2. Proof of Theorem A. We may assume that $k \geqq 3$. Since $n(k-2) /(k+1)$ is an increasing function of $k$, we may assume that $\mathscr{F}$ has a subfamily $\mathscr{B}=\left\{B_{1}, B_{2}, \cdots, B_{k+1}\right\}$ with empty intersection. We may also assume that none of the $B$ 's is the whole circle.

For $1 \leqq i \leqq k+1$, choose antipodal points $a_{i}$ and $a_{i+k+1}$ on the circle belonging to $\cap\left(\mathscr{B}-\left\{B_{i}\right\}\right)$. Relabelling if necessary, assume that $a_{1}, a_{2}, \cdots, a_{2 k+2}$ are in clockwise order on the circle. The arc from $a_{u}$ to $a_{v}$ will be denoted by $\left[a_{u}, a_{v}\right]$, and all subscripts are to be reduced $\bmod (2 k+2)$.

Let $1 \leqq i \leqq k+1$. Since $B_{i}$ is a symmetric twin, we have

$$
\left[a_{\imath+1}, a_{i+k}\right] \cup\left[a_{i+k+2}, a_{i-1}\right] \subset B_{i} .
$$

Thus $x \in B_{i}$ if $x \notin\left[a_{i-1}, a_{\imath+1}\right] \cup\left[a_{i+k}, a_{i+k+2}\right]$. Consequently,

$$
\cap\left(\mathscr{B}-\left\{B_{i+1}, B_{i+2}\right\}\right) \subset\left[a_{i}, a_{i+3}\right] \cup\left[a_{i+k+1}, a_{i+k+4}\right] .
$$

For any $F \in \mathscr{F}-\mathscr{B},\{F\} \cup\left(\mathscr{B}-\left\{B_{i+1}, B_{i+2}\right\}\right)$ is a subfamily of $\mathscr{F}$ of size $k$ and has nonempty intersection. Hence for $1 \leqq i \leqq k+1$,

$$
F \cap\left[a_{i}, a_{i+3}\right] \neq \phi
$$

as $F$ is a symmetric twin.

It follows that each $F \in \mathscr{F}-\mathscr{B}$, being a symmetric twin, contains all of the points $a_{1}, a_{2}, \cdots, a_{2 k+2}$ with the possible exception of 6 . Hence one of these points, say $a$, belongs to at least

$$
\frac{(2 k+2)-6}{2 k+2}|\mathscr{F}-\mathscr{B}|=\frac{k-2}{k+1}(n-k-1)
$$

members of $\mathscr{F}-\mathscr{B}$. The point $a$ also belongs to $k$ members of $\mathscr{B}$. The theorem follows since $(k-2) / k+1)(n-k-1)+k>$ $n(k-2) /(k+1)$.

3. Proof of Theorem B. Let $\mathscr{F}=\left\{F_{1}, F_{2}, \cdots, F_{n}\right\}$. For $0<c<1$, choose $k$ so that

$$
c=1-\sqrt{1-\alpha}
$$


with

$$
\alpha=\left(\left[\frac{k}{2}\right]-2\right) /\left(\left[\frac{k}{2}\right]+1\right)
$$

Let $C$ be a fixed circle in the plane. For $1 \leqq i, j \leqq n, i \neq j$, let $A_{i j}$ be the set of all points on $C$ which lie on straight lines which pass through the center of $C$ and are parallel to some common transversal of $F_{i}$ and $F_{j}$. Clearly $A_{i j}$ is a symmetric twin on $C$. Let $\mathscr{A}$ denote the collection of all these $A$ 's.

Since every subfamily of $\mathscr{F}$ of size $k$ has a common transversal, every subfamily of $\mathscr{C}$ of size [k/2] has nonempty intersection. By Theorem A, $\mathscr{A}$ has a subfamily of size at least $\alpha\left(\begin{array}{l}n \\ 2\end{array}\right)$ with nonempty intersection. Let $x$ be a point in this intersection.

Let $L$ be a fixed straight line perpendicular to the straight line joining $x$ and the center of $C$. For $1 \leqq i \leqq n$, let $G_{i}$ be the projection of $F_{i}$ onto $L$. Clearly $G_{i}$ is a closed interval on $L$. Let $\mathscr{G}$ denote the collection of all these $G$ 's.

For $1 \leqq i, j \leqq n, i \neq j, G_{i} \cap G_{j} \neq \phi$ if $x \in A_{i j}$. Hence at least $\alpha\left(\begin{array}{l}n \\ 2\end{array}\right)$ of the pairs of intervals have nonempty intersection. By Theorem $\mathrm{C}, \mathscr{G}$ has a subfamily of size at least $c n$ with nonempty intersection. Let $y$ be a point in this intersection.

The theorem now follows as the straight line passing through $y$ and perpendicular to $L$ is a common transversal of a subfamily of $\mathscr{F}$ of size at least $c n$.

ACKNOWLEDGMENT. The authors wish to thank the referee for many helpful suggestions which improve the paper's readability.

\section{REFERENCES}

1. H. L. Abbott and M. Katchalski, A Turan type problem for interval graphs, Discrete Mathematics, 25 (1979), 85-88.

2. L. Danzer, B. Grunbaum and V. Klee, Helly's theorem and its relatives, Proceedings of Symposia in Pure Mathematics, 7, "Convexity", Amer. Math. Soc., (1962), 101180.

3. B. Grunbaum and T. Motzkin, On components in some families of sets, Proc. Amer. Math. Soc., 12 (1961), 607-613.

4. H. Hadwiger, H. Debrunner and V. Klee, Combinatorial Geometry in the Plane, Holt, Rinehart and Winston, 1964.

Received November 22, 1977.

TECHNION

HAIFA, ISRAEL

AND

UNIVERSITY OF REGINA

REgina, CANADA S4S 0A2 



\title{
PACIFIC JOURNAL OF MATHEMATICS
}

\section{EDITORS}

\author{
DoNALD BABBITT (Managing Editor) \\ University of California \\ Los Angeles, CA 90024 \\ HUGo RossI \\ University of Utah \\ Salt Lake City, UT 84112 \\ C. C. MOORE and ANDREW OGG \\ University of California \\ Berkeley, CA 94720
}

J. DugundJI

Department of Mathematics

University of Southern California

Los Angeles, CA 90007

R. FINN and J. Milgram

Stanford University

Stanford, CA 94305

\section{ASSOCIATE EDITORS}
E. F. BeCKenbach
B. H. NeumanN
F. WOLF
K. YoshidA

\section{SUPPORTING INSTITUTIONS}

\author{
UNIVERSITY OF BRITISH COLUMBIA \\ CALIFORNIA INSTITUTE OF TECHNOLOGY \\ UNIVERSITY OF CALIFORNIA \\ MONTANA STATE UNIVERSITY \\ UNIVERSITY OF NEVADA, RENO \\ NEW MEXICO STATE UNIVERSITY \\ OREGON STATE UNIVERSITY \\ UNIVERSITY OF OREGON
}

\author{
UNIVERSITY OF SOUTHERN CALIFORNIA \\ STANFORD UNIVERSITY \\ UNIVERSITY OF HAWAII \\ UNIVERSITY OF TOKYO \\ UNIVERSITY OF UTAH \\ WASHINGTON STATE UNIVERSITY \\ UNIVERSITY OF WASHINGTON
}

The Supporting Institutions listed above contribute to the cost of publication of this Journal, but they are not owners or publishers and have no responsibility for its content or policies.

Mathematical papers intended for publication in the Pacific Journal of Mathematics should be in typed form or offset-reproduced, (not dittoed), double spaced with large margins. Please do not use built up fractions in the text of the manuscript. However, you may use them in the displayed equations. Underline Greek letters in red, German in green, and script in blue. The first paragraph or two must be capable of being used separately as a synopsis of the entire paper. Please propose a heading for the odd numbered pages of less than 35 characters. Manuscripts, in triplicate, may be sent to any one of the editors. Please classify according to the scheme of Math. Reviews, Index to Vol. 39. Supply name and address of author to whom proofs should be sent. All other communications should be addressed to the managing editor, or Elaine Barth, University of California, Los Angeles, California, 90024.

50 reprints to each author are provided free for each article, only if page charges have been substantially paid. Additional copies may be obtained at cost in multiples of 50 .

The Pacific Journal of Mathematics is issued monthly as of January 1966. Regular subscription rate: $\$ 84.00$ a year $(6$ Vols., 12 issues). Special rato: $\$ 42.00$ a year to individual members of supporting institutions.

Subscriptions, orders for numbers issued in the last three calendar years, and changes of address shoud be sent to Pacific Journal of Mathematics, P.O. Box 969, Carmel Valley, CA 93924, U.S.A Old back numbers obtainable from Kraus Periodicals Co., Route 100, Millwood, NY 10546.

\section{PUBLISHED BY PACIFIC JOURNAL OF MATHEMATICS, A NON-PROFIT CORPORATION}

Printed at Kokusai Bunken Insatsusha (International Academic Printing Co., Ltd.). 8-8, 3-chome, Takadanobaba, Shinjuku-ku, Tokyo 160, Japan. 


\section{Pacific Journal of Mathematics}

\section{Vol. 86, No. 2 December, 1980}

Graham Donald Allen, David Alan Legg and Joseph Dinneen Ward, Hermitian

liftings in Orlicz sequence spaces ............................... 379

George Bachman and Alan Sultan, On regular extensions of measures ........ 389

Bruce Alan Barnes, Representations Naimark-related to $*$-representations; a

correction: "When is a representation of a Banach $*$-algebra

Naimark-related to a $*$-representation?" ........................ 397

Earl Robert Berkson, One-parameter semigroups of isometries into $H^{p} \ldots \ldots .403$

M. Brodmann, Piecewise catenarian and going between rings ............ 415

Joe Peter Buhler, A note on tamely ramified polynomials ............... 421

William Lee Bynum, Normal structure coefficients for Banach spaces ........ 427

Lung O. Chung, Biharmonic and polyharmonic principal functions ......... 437

Vladimir Drobot and S. McDonald, Approximation properties of polynomials

with bounded integer coefficients .............................

Giora Dula and Elyahu Katz, Recursion formulas for the homology of

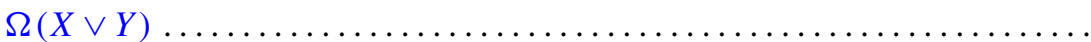

John A. Ernest, The computation of the generalized spectrum of certain Toeplitz operators ...................................... 463

Kenneth R. Goodearl and Thomas Benny Rushing, Direct limit groups and the

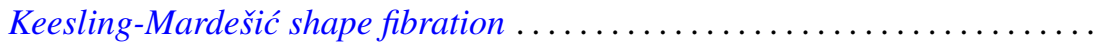

Raymond Heitmann and Stephen Joseph McAdam, Good chains with bad contractions

Patricia Jones and Steve Chong Hong Ligh, Finite hereditary near-ring-semigroups .

Yoshikazu Katayama, Isomorphisms of the Fourier algebras in crossed

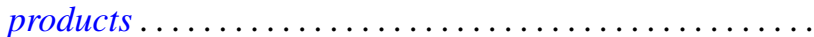

Meir Katchalski and Andrew Chiang-Fung Liu, Symmetric twins and common transversals. .

Mohammad Ahmad Khan, Chain conditions on subgroups of LCA groups ....

Helmut Kröger, Padé approximants on Banach space operator equations ...

Gabriel Michael Miller Obi, An algebraic extension of the Lax-Milgram theorem . .

S. G. Pandit, Differential systems with impulsive perturbation .

Richard Pell, Support point functions and the Loewner variation ...

J. Hyam Rubinstein, Dehn's lemma and handle decompositions of some

4-manifolds

James Eugene Shirey, On the theorem of Helley concerning finite-dimensional subspaces of a dual space.

Oved Shisha, Tchebycheff systems and best partial bases.... 